\title{
ANTIGLIDE PLATING IN D ISTAL FIBU LAR FRACTURE FIXATION IN OSTEOPOROTIC PATIENT
}

By

\author{
HUSSEIN ABD- ALZAHER ABUELGHATT, HESHAM MOHMED \\ SAFWAT AND Khaled Abd-Elwahab Marzouki Ebeid \\ Orthopedics Surgery Department, Al-Azhar Faculty of Medicine
}

\begin{abstract}
Background: Oblique spiral fractures of the distal third of the fibula are commonly encountered in any orthopedics practice. Controversy persists over various fixation methods, and their corresponding risks and benefits. Posterior antiglide plates have been introduced as a method of fixation for the distal part of the fibula.

Objectives: The present study was targeting at the evaluation of radiographic and functional outcome after antiglide plating of distal fibular fracture in osteoportic patient. Functional results were assessed with Weber score system.

Patients and Methods: A prospective study was on 15 patients with distal fibula fracture treated with ORIF.

Results: Posterior plating report increased biomechanical strength, less lateral skin irritation, infrequent need for hardware removal, and ability to use bicortical fixation in the distal fragment.

Conclusion: There was an insufficient evidence to support either posterior or lateral fibular plating as a gold standard. Choice of approach and surgical technique should be individually based on fracture pattern, patient characteristics and surgeon experience.
\end{abstract}

\section{INTRODUCTION}

The incidence of ankle fractures is increasing, And studies have shown that fracture incidence among the elderly has doubled over the last 40 years with an incidence of 187 in 100,000 people a year. Due to its position and characteristics the ankle is subjected to numerous traumas and its fracture is the most frequent among the load-bearing joints (Verhage et al., 2015).

Traumatic injuries in the elderly are becoming increasingly common as a result of the increasing incidence of osteoporosis, longer lives and the more active lifestyle of the modern elderly person. The management of geriatric trauma requires special attention to different details during the preoperative, intraoperative and postoperative periods (Olsen et al., 2013).

The operative treatment of osteoporotic fractures provides a challenge because internal fixation in poorly mineralized bone is difficult. Complications such as implant failure, mal- or nonunion frequently occur Furthermore, nonoperative treatment often does not result in a preferable outcome and is especially in unstable fractures, not always an 
adequate alternative (Seewoonarain et al., 2016).

The operative fixation of ankle fractures in the elderly population also requires a different strategy as these patients are often physically not able to adhere to a non-weight bearing regime. To allow early weight bearing a reinforced construction is necessary. However, this may be challenging due to the concomitant comorbidities such as diabetes, poor skin conditions (Chun et al, 2017).

Several ways to stabilize this fracture have been suggested $\&$ there are several ways to install the synthesis material, the most recent method is posterior antiglide plates which is recently have been introduced as a method of fixation for the fracture of the distal part of the Fibula (Clare, 2008).

There are several arguments in favor of posteriorly placing the plate with ankle fractures, and these arguments have motivated us to attempt to prove these supposed advantages.

The present study aimed to evaluate the radiographic and functional outcome after antiglide plating of distal fibular fracture in osteoporotic patients.

\section{PATIENTS AND METHODS}

We did our operations in Al-Hussein teaching hospital.

The clinical outcomes were calculated according Weber AO score system.

\section{Inclusion criteria:}

1- Osteoporotic patient above 50 years old.
2- Recent distal fibula fracture ether isolated or combined with medial malleolus or posterior malleolus.

3- Sixmonths post-operative follow up.

4- Weber score system.

\section{Exclusion criteria:}

1- Non osteoporotic patient below 50 years old.

2- Neglected old distal fibular fracture.

3- Previous ankle surgery.

4- Loss of follow-up.

5- Pre-existing deformity, disability, and infection.

\section{Preoperative evaluation:}

- A complete history including mechanism of injury, preinjury condition and medical issues were obtained.

- Physical examinations identify open wounds, skin tenting, significant abrasions or contusion and associated injuries.

- Neurological examination was done.

- Vascular examinations including peripheral pulses were performed.

\section{Radiography:}

- X-rays were obtained in the AP, Lateral and may Mortis views.

- CT was done in some cases.

\section{Timing of the surgery:}

- We had a complete and detailed preoperative plan to be sure that all required implants were available.

- The timing of the surgery also varied depending on patient ability for operative intervention and waiting for edema to subside if present. 


\section{ANTIGLIDE PLATING IN DISTAL FIBULAR FRACTURE FIXATION IN}

OSTEOPOROTIC PATIENT

\section{Type of implant:}

- 1/3 tubular plate or Recon plate.

- Cortical, cancellous and locking screws.

- K-wires in various sizes.

- A variety of clamps including small and large Weber clamps.

\section{Pos.tioning:}

1- Supine position: The patient was positioned supine with a small bump under the ipsilateral hip in order to ease access to the fibula, The bump could be removed after lateral fixation for easier access to the medial side.

2- Lateral decubitus: The patient can also be positioned in the lateral decubitus fashion.

\section{Fluoroscopy:}

The C-arm was used for all cases and was brought in from the contralateral side, allowing it to be brought in and out of the surgical field.

\section{Surgical approach:}

In the antiglide technique, the incision was slightly more posterior, over the posterior edge of the fibula, but may be adjusted slightly based on soft tissue considerations. Deeper tissues were incised in line with the skin incision. Care was taken proximally in the wound to avoid injury to the superficial peroneal nerve which crossed the field approximately $7 \mathrm{~cm}$ proximal to the distal tip of the fibula.

The peroneal fascia was divided, and the peroneal tendons and musculature were retracted posteriorly. Care was taken not to enter the peroneal tendon sheath. With gentle elevation of the periostium about the fracture site, the fibula was exposed after careful dissection. The fracture was again exposed, cleaned out, and anatomically reduced and held with a reduction forceps.

Some of proximal retinaculum may need to be released to expose distal fibula. Periosteum was clear off the posterior surface of the fibula.

Fracture reduction: Ideally, an anatomic reduction should be achieved prior to plate application. Reduction was held with a single $\mathrm{k}$ wire or lag screw. If lag screw was inserted, it was applied in a direct posterior direction so as not to interfere with plate application.

In the comminuted zone, the plate was first secured to the distal bone fragment with K-wires or a serrated bone reduction clamp. In the more proximal part of the incision, the plate was similarly secured to the proximal and intact fibula bypassing the comminuted zone. Fibular length can usually be restored by a combination of manual traction, a small distractor, or a push screw.

Plate application: The average plate length was a six-hole plate (range 4-8 holes). One third tubular plate or a Recon plate was applied to posterior surface of the fibula, and the classic technique were fixed with a 6 holes plate.Because the posterior surface of fibula was straight, contouring of the plate was usually not necessary. Due to the lateral bow of the fibula the plate may have to be placed posterolaterally.

Proximal screw insertion: First $3.5 \mathrm{~mm}$ cortical screw was placed proximally through the plate, $2 \mathrm{~mm}$ above the posterior fracture line. If an anatomic reduction has already been achieved, the proximal screw can be tightened down. If an anatomic reduction has not been achieved the screw was not fully tighten. Plate helps prevented proximal gliding of the distal fragment. Bone holding clamps were applied to both fracture fragments 
and the fracture was pulled out to length, and slight internally rotation of the distal fragment. Reduction was achieved with this maneuver. At this point, the proximal screw was tightened down, and remaining proximal $3.5 \mathrm{~mm}$ cortical scews were inserted.

Distal screws insertion: Technically, the more distal screws were not necessary but $4 \mathrm{~mm}$ cancellous screws were inserted at the surgeondissection. Because there was no risk of joint penetration, longer screws can be used and get better hold on bone.
Intraoperative radiographs were taken in all cases to document reduction and fixation.

If fixation of the medial malleolus was required, it can be done with the patient in supine position. Alternatively, indirect reduction by ligamentoaxis of the posterior inferior tibiofibular ligament was attempted.A syndesmotic screw was placed above the distal tibiofibular joint, if the interosseous membrane and anterior and posterior ligaments were torn. The screw has to be removed after 6 to 8 weeks.

\section{RESULTS (Table 1)}

- We studied 15 patients all was over 50 years old.

- The average time interval between admission and surgery was 4.6 days (range 2-7 days).

- The average operative time was 60 minutes (40-80 min).

- All the fractures were united by 6-12 weeks (Average 9 weeks).

- Twelve patients $(80 \%)$ relieved without post-operative complications.

- Three patients (20\%) achieved post-operative complications (mild to moderate pain).

- Only one patient needs syndysmotic screw.

- No cases had metal prominence.

- There was no radiological evidence of degenerative joint disease related to the plate.

- No any patient had reported about deep infection, implant failure or peronial tendenitis.

- All patients began full weight-bearing, with a walking frame, two weeks after surgery.

- One patient (case 3) developed a deep-vein thrombosis, requiring treatment with warfarin.

- There were no cases of delayed union, nonunion, or talar shift. One sendysmotic screw was removed at a mean of 6 weeks.

- They stated that they felt more stable than before their fracture.

\section{Assessment according to Weber score system}

\section{Pain:}

There were 12 cases $(80 \%)$ with no pain took 0 point from the score, there was 2 patients $(13.3 \%)$ with mild pain with high physical activity took 1 point, the last patient $(6.7 \%)$ with mild pain with normal physical activity took 2 point. No recorded cases with pain at rest. 


\section{ANTIGLIDE PLATING IN DISTAL FIBULAR FRACTURE FIXATION IN OSTEOPOROTIC PATIENT}

\section{Walking:}

Fourteen cases $(93.3 \%)$ showing normal toe and heal walking took 0 point, running and sit-ups. 1 case $(6.7 \%)$ show impaired gait but not limping took 1 point from the score.

All 15 patients return to full functional and recreational activity took 0 point from Weber score system.

All of our 15 patients showed perfect anatomy took 0 point from the Weber score and complete symmetrical ankle joint took 0 point from the Weber score there were full mobility and symmetrical mobility took 0 point from Weber score.

The description of result of Weber in studied patients showed 12 cases (80\%) had excellent result, 2 cases (13.3\%) had good result and one case $(6.7 \%)$ had poor result according to Weber score system.

Table (1): Detailed data of the patients.

\begin{tabular}{|c|c|c|c|c|c|c|c|c|c|c|c|c|}
\hline $\begin{array}{l}\mathbf{N} \\
\mathbf{0}\end{array}$ & $\begin{array}{l}\text { se } \\
\mathbf{x}\end{array}$ & $\begin{array}{l}\text { A } \\
\text { ge }\end{array}$ & $\begin{array}{c}\text { Sid } \\
\text { e }\end{array}$ & $\begin{array}{l}\text { Patern of } \\
\text { fracture }\end{array}$ & $\begin{array}{c}\text { Weber AO } \\
\text { classificatio } \\
\text { n }\end{array}$ & $\begin{array}{l}\text { Follow } \\
\text { up } \\
\text { Weeks }\end{array}$ & $\begin{array}{c}\text { Mode } \\
\text { of } \\
\text { traum } \\
\text { a }\end{array}$ & $\begin{array}{c}\text { Wound } \\
\text { Infectio } \\
\mathbf{n}\end{array}$ & $\begin{array}{c}\text { Fractur } \\
\text { e } \\
\text { Non } \\
\text { union }\end{array}$ & pain & $\begin{array}{l}\text { Weber } \\
\text { score }\end{array}$ & $\begin{array}{l}\text { Weber } \\
\text { result }\end{array}$ \\
\hline 1 & F & 57 & Rt & Bimalleolar & $\mathrm{C}$ & 12 & Rolling & none & none & none & 0 & $\begin{array}{c}\text { Excell } \\
\text { ent }\end{array}$ \\
\hline 2 & F & 62 & LT & Bimalleolar & B & 12 & Rolling & none & none & none & 1 & Good \\
\hline 3 & M & 59 & Rt & $\begin{array}{c}\text { Lateral } \\
\text { maleolus }\end{array}$ & $\mathrm{C}$ & 12 & Rolling & none & none & mild & 0 & $\begin{array}{c}\text { Excell } \\
\text { ent }\end{array}$ \\
\hline 4 & $\mathrm{~F}$ & 70 & Rt & $\begin{array}{l}\text { Bimalleolar } \\
\text { with } \\
\text { syndesmotic } \\
\text { Injery }\end{array}$ & B & 16 & Rolling & none & none & $\begin{array}{l}\text { mod } \\
\text { erate }\end{array}$ & 3 & Fair \\
\hline 5 & M & 64 & Rt & Bimalleolar & B & 12 & Rolling & none & none & none & 0 & $\begin{array}{c}\text { Excell } \\
\text { ent }\end{array}$ \\
\hline 6 & F & 58 & Lt. & trimalleolar & A & 14 & RTA & none & none & none & 0 & $\begin{array}{c}\text { Excell } \\
\text { ent }\end{array}$ \\
\hline 7 & M & 67 & Lt. & Bimalleolar & B & 16 & Rolling & none & none & none & 0 & $\begin{array}{c}\text { Excell } \\
\text { ent }\end{array}$ \\
\hline 8 & $\mathrm{~F}$ & 61 & Rt. & bimalleolar & B & 12 & Rolling & none & none & none & 0 & $\begin{array}{c}\text { Excell } \\
\text { ent }\end{array}$ \\
\hline 9 & $\mathrm{~F}$ & 54 & Rt. & $\begin{array}{l}\text { Lateral } \\
\text { malleolus }\end{array}$ & $\mathrm{C}$ & 14 & Rolling & none & none & none & 0 & $\begin{array}{c}\text { Excell } \\
\text { ent }\end{array}$ \\
\hline 10 & F & 57 & RT & bimalleolar & B & 12 & Rolling & none & none & none & 0 & $\begin{array}{c}\text { Excell } \\
\text { ent }\end{array}$ \\
\hline 11 & M & 65 & Lt. & bimalleolar & B & 16 & Rolling & none & none & mild & 1 & Good \\
\hline 12 & F & 74 & Lt. & bimalleolar & B & 12 & Rolling & none & none & none & 0 & $\begin{array}{c}\text { Excell } \\
\text { ent }\end{array}$ \\
\hline 13 & $\mathrm{~F}$ & 59 & Rt. & $\begin{array}{c}\text { Lateral } \\
\text { malleolus }\end{array}$ & $\mathrm{C}$ & 16 & Rolling & none & none & none & 0 & $\begin{array}{c}\text { Excell } \\
\text { ent }\end{array}$ \\
\hline 14 & M & 72 & Rt. & bimalleolar & A & 14 & Rolling & none & none & none & 0 & $\begin{array}{l}\text { Excell } \\
\text { ent }\end{array}$ \\
\hline 15 & $\mathrm{~F}$ & 56 & Lt. & $\begin{array}{c}\text { Isolated } \\
\text { lateral } \\
\text { malleolus. }\end{array}$ & B & 12 & Rolling & none & none & none & 0 & $\begin{array}{c}\text { Excell } \\
\text { ent }\end{array}$ \\
\hline
\end{tabular}




\section{HUSSEIN ABD- ALZAHER ABUELGHATT et al.}

\section{DISCUSSION}

Fractures of the fibula are common injuries treated by orthopedic surgeons. The typical Weber B ankle fracture is caused by an Supination external rotation mechanism according to the LaugeHansen classification. The SER pattern of ankle fracture comprises up to $85 \%$ of all ankle fractures (Rina et al., 2017).

In 1982, Brunner and Weber proposed the use of a posterior antiglide plate as a new method of fibular fixation. They concluded that posterior plating was advantageous as it was biomechanically superior and avoided the soft tissue complications associated with subcutaneous plate placement (Amorosa et al., 2010).

In pulling the fibula out to length, the ankle mortise is restored. Assessment of restoration of the ankle mortise can be assessed by radiographic measurements of the medial clear space $<4 \mathrm{~mm}$ after reduction, tibia-fibula (tib fib) overlap > $10 \mathrm{~mm}$ on anterior-posterior (AP) view 1 $\mathrm{cm}$ superior to the ankle joint, and talar tilt $<10$ degrees. As with all fractures, the goal of rigid, internal fixation and anatomic reduction should be achieved (Amorosa et al., 2010).

The classical Weber type B fracture, with its short oblique course, has a typical displacement with shortening and dorsolateral movement of the distal fragment. During application of the plate dorsolaterally, the fracture reduces automatically while the plate acts as a buttress or antiglide plate rather than a neutralization plate. In these special cases there is no need to use interfragmentary compression screws. Functional postoperative treatment is possible, even when the plate has been applied without insertion of screws into the distal fragment (Hess and Sommer,2011).

Buscharino et al. (2013) simulated Danis-Weber type-B fractures and assess the mechanical resistance of osteosynthesis with interfragmentary lag screw and lateral and posterior plates, which are subject to supination stress and external rotation. They concluded that there is no significant difference between the posterior plates or the lateral plates in the Danis-Weber type-B ankle fractures when subjected to bending strength (simulating supination). When subject to torsional forces (simulating external rotation), the posterior plate has proven to be statistically more rigid than the lateral plate.

Pull out strength comparison for unicortical and bicortical distal ?bular screws. As a result, it was determined that bicortical screws had 2 to 3 times greater pullout strength than did unicortical screws (Dhameliya, 2016).

Minihane et al. (2006) in a cadaver model, compared lateral locked plating with posterolateral antiglide plating for the ?xation of a distal ? bula fracture and showed that the antiglide plate had improved stability as compared to the lateral locking plate (Charles, 2011).

Weber and Krause (1982) found that $30(43 \%)$ of 70 patients who had undergone posterior antiglide plating experienced postoperative discomfort because of peroneal tendinitis, requiring hardware removal. Nine of the $30(30 \%)$ patients who required hardware removal displayed gross intraoperative evidence of peroneal tendinopathy (Li, 2017). 
OSTEOPOROTIC PATIENT

In retrospective series reported by Lamontagne et al. (2002) comparing lateral and posterior anti-glide fixation of the distal fibula, the authors found a trend toward increased incidence of hardware removal (17\% vs $13 \%)$, discomfort (12\% vs $7 \%$ ), and wound dehiscence or infection (4\% vs $1 \%)$ for lateral plate fixation when compared to a posterior antiglide plate, although these differences were not statistically significant. Moreover, they found no statistically significant difference in operative time, tourniquet time, or length of hospital stay (McFadyen, 2011).

Brunner and Weber (1982) described ? bular fracture ?xation using the antiglide plate. Schaffer and Manoli compared the mechanical strength of lateral plating using a tubular plate to that of ?xation using a posterior antiglide plate. They found no difference in ?xation strength in healthy bones, although posterior antiglide plating showed greater ? xation strength in osteoporotic bones. In a cadaver study, Minihane et al found that posterior antiglide plating with a short, tubular plate is biomechanically stronger in osteoporotic bone than lateral plating using a long, one-third tubular locking compression plate (Ahn et al., 2016).

\section{CONCLUSION}

The operative fixation of ankle fractures in the elderly population requires a different strategy as these patients are often physically not able to adhere to a non-weight bearing regime. To allow (early) weight bearing a reinforced construction is necessary.

In 1982 Brunner and Weber proposed the use of a posterior antiglide plate as a new method of fibular fixation. They concluded that posterior plating was advantageous as it was biomechanically superior and avoided the soft tissue complications associated with subcutaneous plate placement.

The use of posterior plating in lateral malleolus fixation remains controversial. Advocates of posterior plate application argue that the concern for intraarticular screw penetration is avoided with posterior to anterior screw placement. Other potential benefits include less dissection and operative time, minimum bending of the plate, and the fact that distal screw fixation may be unnecessary.

Greater resistance has been observed with posterior plating, and a greater number of patients report satisfactory results regarding the positioning of the plate in the posterior position.

\section{REFERENCES}

1. Amorosa LF, Brown GD and Greisberg J (2010): A surgical approach to posterior pilon fractures. J Orthop Trauma 24:188-193, 2010.

2. Buscharino B, Moretti RG and Hungria JOS (2013): Biomechanical study: Resistance comparison of posterior antiglide plate and lateral plate on syntehtic bone models simulating Danis-Weber B malleolar fractures. Rev Bras Ortop; 48(3): 221-227.

3. Charles N. Cornell , OmriAyalon (2011): Evidence for Success with Locking Plates for Fragility Fractures.HSSJ, 7: 164-169.

4. Clare P (2008): A Rational Approach to Ankle Fractures Foot Ankle. Foot Ankle Clin N Am $13,593-610$.

5. Chun D, Sharma AR, Kim Y, Ulagpan A, Jagga S, Lee $S$ and Cho J (2017): A novel remedy for isolated weber $\mathrm{b}$ ankle fractures: surgical treatment using a specialized anatomical locking plate. The Journal of Foot \& Ankle Surgery, 54: 288-294. 
6. DilipDhameliya andPrashanth G (2016): Clinical evaluation of ankle fracture at a Tertiary care hospital. International Journal of Orthopaedics Sciences, 2(4): 287-289.

7. Hess F andSommer C (2011): Minimally invasive plate osteosynthesis of the distal fibula with locking compression plate: first experience of 20 cases. J Orthop Trauma, 25:110-115.

8. Jungtae A, Sehun K, Jung L, Kyungjei W and $\mathrm{Ki} S$ (2016): Incidence of PeronealTendinopathy After Application of a Posterior Antiglide Plate for Repair of Supination External Rotation Lateral Malleolar Fractures. The Journal of Foot \& Ankle Surgery,55: 90-93.

9. McFadyen I and Adeel A (2011): The osteoporotic ankle fracture. orthopaedics and trauma journal,25:4 253.

10. Mengnai $L$, Rachel $C$, Nathaniel $S$ andThuan V (2017): Comparing Different Surgical Techniques for Addressing the Posterior Malleolus in Supination External Rotation Ankle Fractures and the Need for
Syndesmotic Screw Fixation. The Journal of Foot \& Ankle Surgery, 56: 730-734.

11. Olsen, Hunter, JR, Judith F and Baumhauer JF (2013): Osteoporotic Ankle Fractures. International Journal of Orthopaedics Sciences, 3(2): 445-448.

12. Sakai R, Uchino M, Yoneo T, Ohtaki Y, Minehara H, Matsuura T, Gomi $T$ and Ujihira M (2017): Influence of hooks and a lag screw on internal fixation plates for lateral malleolar fracture: a biomechanical and ergonomic study. Journal of Orthopaedic Surgery and Research, 12:34-37.

13. Seewoonarain, Prempeh M, Shakokani M and Magan A (2016): Ankle Fractures: Review Article.Seewoonarain et al., J Arthritis, 5:1-33.

14. Verhage,I. S. M. Schipper B. and Hoogendoorn J. M. (2015): Long-term functional and radiographic outcomes in 243 operated ankle fractures. Foot and Ankle Research. Journal of Foot and Ankle Research, 8:45-62. 


\section{الثريحة مانعة الانز لاق لتثييت كسور أسفل عظمة الشظية في مرضى هشاشة العظام}

حسين عبد الظاهر حسين أبو الغيط ، هشام محمد صفوت ، خالد عبدالوهاب مرزوقي عبيد قسم جراحة العظام-كلية الطب_جامعة الأزهر

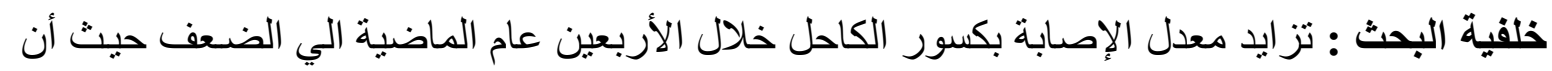

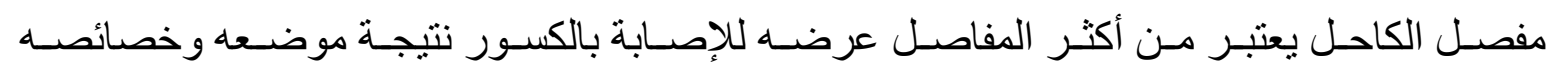

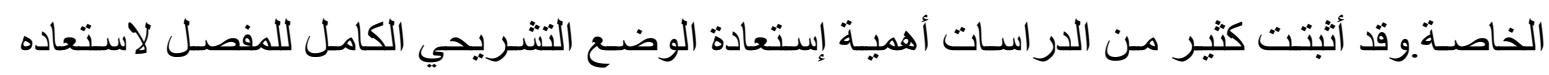

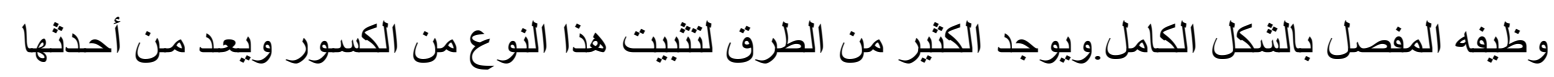
الثريحة مانعة الإنز لاق التي قدمت مؤخر ا كأحدث طريقة لتثبيت كسور أسفل عظمة الثظية.

الهدف من البحث: تقييم الحالـة الوظيفية للمرضى بعد تثبيت كسور أسفل عظمـة الثظية باستخدام الثريحة مانعة الإنز لاق في مرضى هشاثة العظام. قد تم التقييمإعتمادا على نظام (و عيير) للتقبيم.

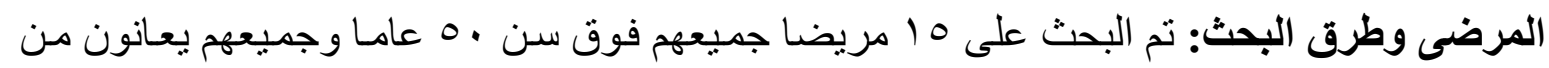

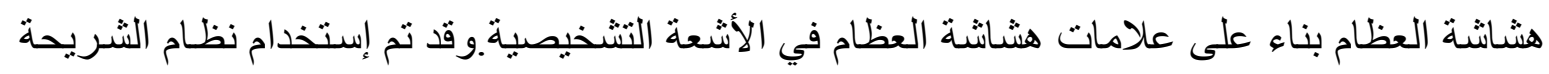

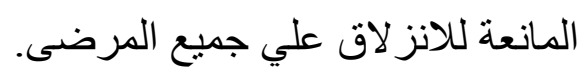

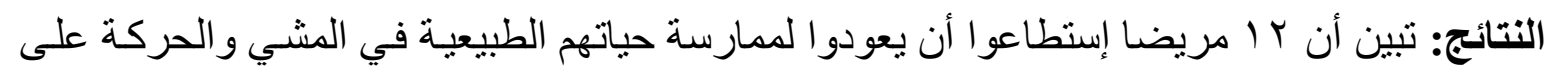

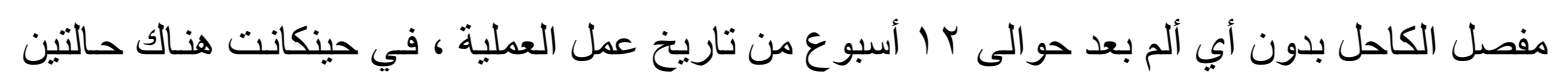

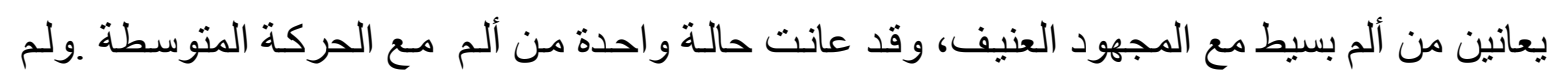

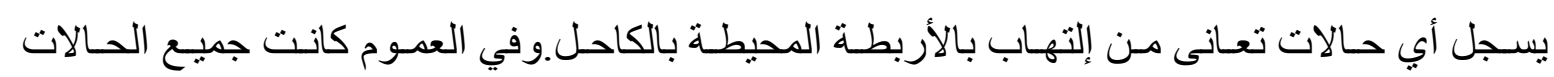
راضية تماما عن نتيجة الجر احة.

الاستنتاج: الوضع الخلفي المانع للانز لاقفي تثبيت كسور أسفل الثظية أفضل للمريض الذى يعانى من

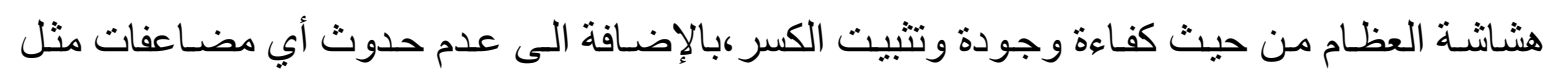

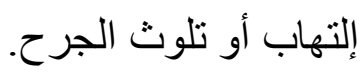

